\title{
RESEARCH IN CANADA
}

\author{
By Lieut.-General a G. L. McNaughton, C B., C.M.G., D.S.O. \\ Formerly President, National Research Council of Canada; General Officer \\ Commanding ist Canadian Corps Overseas Forces
}

\section{The National Research Council}

$\mathrm{T}$ HE organization of research in Canada as a function of government dates back to 1916, when an honorary Advisory Council for Scientific and Industrial Research was set up. It was not contemplated at that time that this Council would establish laboratories of its own; it was to act as an agency for consultation and coordination between those already carrying on research in the existing laboratories of the several departments of the Dominion and Provincial Governments, in the universities, and in industry.

A report prepared at the time indicates that the total annual expenditure on research in all governmental laboratories, both Dominion and Provincial, amounted to considerably less than 100,000 dollars ; and that of some 2,400 leading Canadian firms engaged in manufacturing who replied to the questionnaire, only 37 had laboratories which even pretended to engage in research.

As a result of the pressure of public opinion concerning these limited facilities, the matter was repeatedly considered in Parliament, and, eventually the Research Council Act was passed in 1924 .

The Council's main laboratories, situated at the junction of the Ottawa and Rideau Rivers, were commenced in 1930 and opened at the time of the Imperial Economic Conference in 1932.

By 1939 the Council's annual budget on current account was somewhat more than a million dollars. Meanwhile an even more striking increase had taken place in the facilities in Canadian industry itself, and by 1938 it is estimated that these comprised upwards of 1,000 industrial laboratories for research, testing and plant control, with some 2,500 professional workers employed full time. Similarly in the Dominion Departments of Agriculture, of Public Works, of Mines and Resources the last two decades have seen the creation of a number of research and testing laboratories related to their special functions and duties, all of which represent a very substantial asset. Elsewhere the most notable addition was the Ontario Research Foundation, which operates in the most friendly relations with the National Research Council.

In 1938 provision for a further large group of laboratories to provide the Council with additional

* Substance of a paper read before the Royal Society of Arts on May 13. facilities, particularly for aeronautical engineering, hydraulics and high-voltage electrical engineering, was sanctioned by the Government. Construction was started in 1939, and is now advanced to the point that in some cases the buildings are in occupation.

As a result of these measures, at the outbreak of the present War, Canada had the laboratories and trained staffs competent to act as a nucleus in undertaking the study of the problems presented in almost every field of war requirements both within the sea, land and air forces themselves and also in the industrial life of the country as it had to be re-oriented to produce the vast and complicated supplies needed in transition from a peace to a war basis.

But the adequacy of physical equipment and technical staff is only one side of the question, and what is probably equally important as an asset is the organization of the Council itself as a going concern, and the intimate relations which had been developed with every branch of science in Canada-with universities, with industry, with departments of the Dominion and Provincial Governments concerned with research problems, with the great professional societies in medicine, engineering, forestry, etc., with the Canadian Engineering Standards Association in the field of industrial standardization, and many others.

The National Research Council consists of fifteen members selected for terms of three years from among men prominent in scientific work in Canadian universities or in Canadian industry. The Council is required by statute to meet at least four times annually in Ottawa. There is a president, appointed by the Governor in Council for a term of years, who reports directly to the Privy Council Committee on Scientific and Industrial Research of which the Minister of Trade and Commerce is the chairman. The office of president is now filled by Dean C. J. Mackenzie, professor of civil engineering in the University of Saskatchewan.

Apart from administration, which is organized much on the usual lines of a department of Government, the staff of the Council is grouped in a number of divisions each under a director.

The Divisions of Physics and Electrical Engineering, Chemistry, Mechanical Engineering including Hydraulics and Aeronautics, Biology and Agriculture are responsible for the direction and 
conduct of the technical work in the fields indicated by their designations. There is a Section on Research Plans and Publications concerned with the collection, collation and issue of scientific information and with the general development of co-operative investigations through committees, etc. There is also a Section on Codes and Specifications, matters which are in the highest degree important in relation to mass production in war. Provision is made for the closest co-operation and collaboration between all branches concerned in any particular problem.

One of the great advantages possessed by an organization such as the Council's own laboratories with their comprehensive representation of all branches of science is that experts in every line required can be brought together at short notice to study a problem and to work as a team for its solution. This facility is very important, for in most research problems related to industrial or agricultural production or processing we are usually confronted with limiting factors of many kinds, and it is not easy in advance to determine in which branch of science the answer should be sought. For example, in a recent study of the cold storage of chicken which had developed a defect called 'freezer burn', which spoiled the appearance and marketability of the birds, the work started in the hands of biologists and mycologists on the supposition that a fungus was involved ; then chemists were required to study the breakdown products, and in the end the answer was found to lie in the very precise control of humidity at low temperatures- $-a$ solution contributed by the physicists and engineers.

\section{Associate Committees and Co-operative RESEARCH}

In order to bring to bear the knowledge of scientific men in other institutions and in industry and to correlate the work of research in all organizations concerned, a number of so-called Associate Committees have been set up. The function of these Committees is to direct co-operative research on the problems assigned to them ; to settle the objectives; to indicate the individuals or organizations which should undertake the several component parts of the inquiry; to receive and co-ordinate the resulting information; and to make it available to those who will turn it to advantage.

The Council endeavours to ensure that these Committees are comprehensively representative of all interests and we expect them, each in their proper sphere, to form a national plan into which all who are in a position to contribute information can fit their own particular lines of research. The actual investigations are carried out, not only in the Council's laboratories, but also in the laboratories of the various universities, Government departments and industrial institutions throughout the country; also much of the initiative in these Committees lies with the outstanding experts from other organizations who have associated themselves with the Council in this work.

Time does not permit me to recite to you the long list of these associate committees or to go into, in any detail, the important tasks which they are carrying out for Canada. But, in order to carry some picture of the wide range of work involved, I would, however, by way of illustration, like to mention one or two in several diverse fields.

In agriculture I would mention the Committees in charge of Grain Research and of Transport and Storage of Food; these, both by reason of the great importance of the subjects and also on account of the very substantial results which have been achieved in comparison with the trifling expenditures of money which have been made.

The Grain Research Committee is a co-operative organization with the Department of Agriculture, on which the western grain growers, provincial agriculture departments, plant breeders, etc., are represented. It has developed new varieties of rust-resisting wheat, and these have been thoroughly tested, not only from the rust-resisting point of view, but also for their milling and baking qualities. We have every confidence in them and they have now been multiplied and the seed made available in considerable quantities for use in the areas where rust is most likely. Canada has suffered losses due to rust alone of $100,000,000$ dollars in a single season. If we can take that element of hazard out of the grain-growing business it tends to put it on a better basis and gives some increased assurance to the farmer as to what he will reap when he has sown.

With Canada's mounting surpluses in wheat which she could not market in consequence of the changing policies of European countries towards self-sufficiency in growing their own grain, she has had to turn the attention of her farming committees more and more to livestock and poultry, and the work of the Committee on Transport and Storage of Food, another joint undertaking with the Department of Agriculture, has extended all the way from detailed investiga. tions of the Canadian ports to determine plans for the cold-storage facilities needed for this trade to the conduct of a bacon survey in the United Kingdom.

In forestry, I would mention the Committee organized in co-operation with the Forest Service of the Department of Mines and Resources. This Committee has concerned itself with such matters 
as the study and mitigation of forest hazards, through fire, insects and other pests; with the preparation of a manual giving advice as to the management of the 'farmer's woodlot', a most important source of raw material. This manual is now in general use in the Maritime Provinces and Quebec.

Perhaps the most interesting project is concerned with tree breeding, which a few years ago would have been deemed a fantastic enterprise because of the hundreds of years which would have been required to bring into existence a new tree species and fix its characteristics; but now we have colchicine, a drug which, administered to a plant shortly after pollination, causes a very great increase in the varieties or sports to occur in the next generation, thus giving wide scope to the plant breeder for selection. Nothing occurs which would not otherwise occur naturally, but you may get, if you are fortunate, in a single small plot, in a single season, a multiplicity of varieties which otherwise would take years of patient work to collect.

Another interesting line of research which is being developed by this Committee is the vegetative reproduction of desirable species through the use of plant hormones, a number of which were first synthesized and introduced to science from the chemical laboratories of the National Research Council.

These very remarkable substances in minute, almost microscopic, doses have the property of stimulating root formation. By treatment with these hormones, cuttings of plants, which otherwise would normally not root, can often be induced to do so. One important use of this technique is in the reafforestation of areas where the trees have been destroyed by some pest like the white pine blister rust. Even in the worst areas some trees survive due to some natural inherent resistance. Cuttings from these trees are taken, treated with hormones, rooted and grown in the nurseries as planting stock. These young trees have all the natural heritable characteristics of the original tree from which they came and thus are immune to the disease in question.

I could continue with examples of the work of many other associate committees in the fields of medicine, chemistry, physics and engineering; of the detailed and exacting work carried out by joint committees with the Department of Finance in the preparation of a National Building Code for Canada which is now, despite the War, in process of publication and which should bring order into a situation which, under the conflicting jurisdictions of municipality, province and dominion had become most seriously confused to the disadvantage of the public.
I would just like to record my tribute to the co-operating institutions and to the hundreds of men and women with special scientific or industrial training and experience who, without any remuneration whatever, have associated themselves with the Council in this work and out of whose collaboration many important and useful developments have been and are being brought to a successful conclusion.

\section{AsSISTED ReSEARCHES}

In order to make use of the facilities for research which exist in a number of Canadian universities and to encourage their further development, the Council in the early years of its existence instituted a system of assisted researches through which the professors in charge could be given financial assistance for the provision of needed apparatus, laboratory help and similar out-of-pocket expenses other than their own salaries.

Applications for these are most sympathetically considered; much useful work has been accomplished of value both for the new knowledge secured and, perhaps even more important, for the training given to the workers.

\section{SCHOLARSHIPS}

Another aspect of the Council's concern with the training of research workers is represented by the scholarships which each year are awarded to some seventy or more post-graduate students. These are tenable at Canadian universities or, in special cases, abroad. Through these scholarships which are being given year by year in increasing numbers, in addition to providing the needed supply of highly trained research workers, a deliberate attempt has been made to assist the building up of the post-graduate schools in the Canadian universities.

\section{ENCOURAGEMENT OF RESEARCH IN UNIVER- SITIES, ETC.}

While the National Research Council has itself a number of very well-equipped laboratories in all lines, yet there has been no attempt to monopolize research ; in fact, the very opposite, for it has long been realized that for the safety of the nation against peace-time industrial competition, let alone to meet the needs in war, you can never have too much research.

In Canada the difficulties are particularly acute for, as is well known, most of her principal industrial companies have affiliations with larger organizations abroad to whom there has been a natural tendency to refer any research problems that arise from time to time. It is often very difficult to examine these problems completely 
apart from the special environment in which they have come to attention and the solutions proposed are often, therefore, inadequate, and, both on this ground and on account of delays, very heavy losses are involved.

A more serious loss is due to the fact that without a corps of trained investigators on the spot, the needs of the situation are not fully appreciated and many opportunities for useful inventions and developments are missed or unduly delayed.

\section{RESEARCH INFORMATION AND INTERNATIONAL AfFiliations}

In peace-time, in order to maintain contact with research work going on all over the world, the National Research Council maintains membership in the principal international scientific conferences and meetings, arranges for Canadian representation where required and collects in its library in Ottawa for reference, copies of all papers, proceedings and other information of importance. This is made available as desired to Canadian workers.

For many years also the Council has maintained the closest possible contacts with the Department of Scientific and Industrial Research and the British Standards Institution in Great Britain. These contacts were much strengthened and developed by the Imperial Conference of 1930 and the Imperial Scientific Conference of 1936 and again in August 1939, on the occasion of the visit to Great Britain of a representative group of Canadian manufacturers who had come to Great Britain to familiarize themselves with the needs of war-time industry so that Canadian production could be directed to those articles which would be most required and most useful.

\section{WAR-Time DeVElopMentS}

So far as war-time developments are concerned, I am under the difficulty that no specific information which would be of value to the enemy can be disclosed, so I have to content myself with a few illustrative statements which must be rather general in character.

First, as regards finance, the funds placed at the disposal of the Council for the current year by votes from Parliament and grants-in-aid from the Naval, Land and Air Forces in the Department of National Defence are some fivefold greater than for the last pre-war year. In addition the Council and its technical staff will be responsible for the scientific and technical organization and advice in connexion with other projects not directly administered, which will involve about twice to three times as much again.

Further, in order to provide some measure of elasticity in the finances of the Council, a number of Canadian corporations, large and small, and private individuals have joined together to establish a trust fund of much more than a million dollars, with more available if required. The committee in charge has been enjoined by the donors to make it its business to ensure that no worthwhile project of research, related to the war effort of Canada, which is sponsored by the National Research Council, should be delayed or hampered by lack of money. In this public-spirited group the mining industries of Canada have, as usual, been conspicuous for their generous support of research. Another example of the assistance received from this source is the support given to the Canadian Corps in the organization and equipment of their tunnelling companies. One of these, as is well known, is now at Gibraltar making effective use of the modern machinery presented by the Canadian mining industry. The other Company is using similar equipment in Great Britain.

What is, in effect, a further additional expansion of the Council's activities is represented by Research Enterprises, Ltd., a wholly owned Government corporation which has been set up by the Canadian Ministry of Supply primarily to produce for the armed forces and for industry, inventions and apparatus which had been developed in the Council's laboratories. Already, optical instruments, including gun sights and range finders, radio gear and similar articles, are in production in the large new factory which has been erected, and very shortly the company will be turning out its own supplies of optical glass in quantity.

Thus a small nucleus established in the optical and radio laboratories in the years before the War has been given substance and developed into a key industry of essential importance for our war effort.

The Council's Metrology Laboratories are another example of a small but effective nucleus which has been expanded to large dimensions to care for the standardization of the vast numbers of gauges necessary in the munitions industry.

In the field of radiology, special attention has been paid in the Council's laboratories for many years to the examination of castings, particularly those in light alloys required to carry stress in aircraft construction. Working with the producers the technique of making sound castings had been developed before the War to a high degree of perfection, and the knowledge of this art is now proving of great value to the Canadian aircraft industry.

$\mathrm{X}$-ray photographs up to $600 \mathrm{kv}$., which is sufficient to penetrate several inches of steel, can be taken. For greater thicknesses a plentiful supply of radium is available by reason of the fact that 
the bulk of the world's new supply derived from the mines at Great Bear Lake and refined by the Eldorado Company at its Port Hope plant comes to the Council for test and certification.

Turning to another of many fields, I would like to mention the very important programme which has been initiated by the Committee on Aviation Medicine under the chairmanship of the late $\mathrm{Sir}$ Frederick Banting. It was on the business of this Committee that Sir Frederick was proceeding to England when he lost his life in a flying accident (see NATURE of May 3, p. 535).

All this great range of work of which I have been speaking is going forward in Canada in the closest sympathy and understanding both with the authorities in Great Britain and also with our mutual friends and colleagues in the United
States. In order to help in the maintenance of effective contact the British Government has established a Scientific Liaison Office with the Council in Ottawa and we have been privileged to receive first Prof. R. H. Fowler and more recently Sir Lawrence Bragg.

At the present time a number of the senior members of the National Research Council are in England to familiarize themselves with the latest methods and requirements so that work in Canada may be kept related to problems of immediate practical importance.

There is a constant flow and interchange of workers and the various problems are taken up as available facilities best indicate. Needless to say, there is no delay or reservation in making the results available for application and use.

\section{TERCENTENARY OF NEHEMIAH GREW (I64I-I7I2)}

\section{By Dr. Agnes Arber}

$\mathrm{N}^{\mathrm{k}}$ EHEMTAH GREW will always be held in honour by botanists as the co-founder with Marcello Malpighi of the science of plant anatomy. It is true that in his ideas about plant cells he did not advance much beyond Robert Hooke, who, in 1665, figured and named these units; but, as regards knowledge of vascular structure, the position is very different. Grew and Malpighi not only initiated the study of the bundle system of the flowering plant, but also carried it to a surprisingly high level, considering that they had to start from the very foundations. Grew's first book, "The Anatomy of Vegetables Begun" (1672), contains the earliest printed illustration showing vascular bundles as seen in section under the microscope. He followed up this work in 1673 and 1675 by treatises on the detailed anatomy of roots and of stems. Finally he brought all his results together, in 1682, in a splendidly illustrated folio, "The Anatomy of Plants", which included improved second editions of his first three books, as well as much additional matter. The excellence of Grew's botanical morphology and anatomy has been recognized fully; indeed his reputation in this line is deservedly so great that it has tended to overshadow the other facets of his output. It seems worth while, therefore, in this, his tercentenary year, to direct attention to certain less specialized aspects of his scientific work.

Grew's general attitude towards biology cannot be understood unless one realizes how deeply he was committed to a mechanistic view of the universe. It seems likely that Hooke, and also Descartes, had to some extent turned his mind in this direction, though in the seventeenth century such ideas were so much in the air that it is scarcely necessary to look for specific sources. It was owing to the mechanistic viewpoint of that period, that the microscope, for example, was hailed as an instrument which was destined to clear away all inconvenient mysteries. Hooke hoped that by the help of glasses "we may perhaps be inabled to discern all the secret workings of Nature, almost in the same manner as we do those that are the productions of Art, and are manag'd by Wheels and Engines, and Springs, that were devised by humane Wit'. Grew enlarges upon this analogy between the world and a man-made machine, and seems to find it entirely satisfying. He says that "all Nature is as one Great Engine made by and held in" the hand of God. He regards this engine as having been set in motion by the Great First Cause, to which all subsequent effects can be traced back; he considers that the original causation was all that was necessary, and that, in the normal course of events, no subsequent interference has occurred. "And as it is the watch. maker's Art," he says, "that the Hand moves regularly from hour to hour, although he put not his finger still to it: so it is the demonstration of Divine Wisdom, that the Parts of Nature are so harmoniously contrived and set together as to conspire to all kind of natural motions and effects without the extraordinary-immediate influence of the Author of it."

This particular philosophy led Nehemiah Grew to regard it as a pious duty to discover a mechanistic "cause" for each phenomenon; he defines 